\title{
A Review on the Impact of Body Mass Index on Outcomes in Pediatric Leukemia
}

This article was published in the following Dove Press journal:

Journal of Blood Medicine

\author{
Annalisa Paviglianiti \\ Department of Hematology and Stem \\ Cell Transplantation, Saint Antoine \\ Hospital, AP-HP, Paris, France
}

\begin{abstract}
In the last decades, adults and pediatric obesity have become a major issue in developed countries. Considerable research has been conducted in patients with acute lymphoblastic (ALL) and myeloid leukemia (AML) with the aim of correlating body mass index (BMI) and outcomes in patients undergoing chemotherapy for hematological diseases. In adults, a high BMI has been associated with increased leukemia-related mortality. Whether a similar effect exists in the pediatric setting remains controversial. Some of the studies detailed in this review have reported no differences in outcomes according to BMI, whilst other reports have described higher treatment-related mortality, increased risk of relapse and death. Although the link between BMI and acute leukemia outcomes is controversial, a large number of studies describe poorer survival rates in children with AML or ALL with higher BMI. On the other hand, being underweight has been associated with higher treatment-related toxicity. Understanding more about the impact of BMI in pediatric leukemia is of utmost importance to provide prompt intervention and improve outcomes.
\end{abstract}

Keywords: BMI, acute leukemia, AML, ALL, HCT

\section{Introduction}

Acute leukemia is one of the most common pediatric cancers. ${ }^{1}$ Acute lymphoblastic leukemia (ALL) is rare in infants (less than 1 year old), but becomes more frequent in toddlers and other children, with a peak incidence at the age of 2 to 5 years old. Acute myeloid leukemia (AML) is less frequently observed, representing $15 \%$ to $20 \%$ of all childhood leukemia and $30 \%$ of adolescent leukemia. After a peak during the first 2 years of life, the subsequent low annual incidence of AML slowly increases after the age of 9 years.

Among the factors that could affect prognosis in children with ALL and AML, nutritional status has been largely investigated. ${ }^{2}$

One of the most used means to evaluate the nutritional status is the body mass index (BMI). BMI represents the measure of appropriateness of weight for a given height. It is calculated by dividing weight in kilograms by height in square meters. In growing children, BMI distribution changes significantly according age and gender. Hence, BMI percentiles by age and sex are used to classify the appropriate BMI in children from the age of 2 years old (the use of the BMI chart is not recommended for clinical use before age two years). ${ }^{3}$ Patients are classified according to BMI as normal (5th-84th percentile), underweight ( $<5$ th percentile), overweight (85th-95th percentile) or obese ( $>95$ th percentile) using the Centers for Disease Control and Prevention growth charts for age and gender. ${ }^{4}$ Another
Correspondence: Annalisa Paviglianiti Department of Hematology and Stem Cell Transplantation, Hôpital Saint Antoine, 168 Rue du Faubourg Saint Antoine, Paris 75012 , France Tel +33(0) I 42494823

Email annalisa.paviglianiti@gmail.com 
WHO classification provided by the World Health Organization (WHO) is the BMI for age $z$ score. Using the WHO classification patients are divided in normal ( -1.9999 to 0.9999$)$, wasted ( -2 to 2.9999$)$, severely wasted ( $\geq-3)$, at risk of overweight (1 to -1.9999$)$, overweight (2 to 2.9999 ) and obesity $(\geq 3)$.

Recent findings in pre-clinical studies demonstrate alterations in the microenvironment associated to obesity, with chronic low-grade inflammation present in the tumor microenvironment. ${ }^{5}$ Moreover, several studies demonstrate that obesity is associated with alterations in tissue composition and an increased circulating blood volume. These parameters can alter drug pharmacokinetics at all levels (absorption, distribution, metabolism and elimination). ${ }^{6,7}$

Being obese or underweight at diagnosis has been widely studied in the setting of cancer, and it has been associated with the higher risk of mortality or diseaserelated outcomes by several authors. Two landmark analyses in the pediatric setting have been performed with the aim of examining the susceptibility of malnourished or overweight children with acute leukemia to relapse or death. The first study was conducted in AML pediatric patients and described high treatment-related mortality in obese patients after intensive chemotherapy. ${ }^{8}$ The second one, performed in a large cohort of children with ALL, demonstrated a poorer event-free survival in children with higher BMI. ${ }^{9}$

Since then, many other studies have been conducted in the pediatric setting, reporting controversial results.

Recently, several meta-analyses have been conducted in cohorts of ALL and AML pediatric patients (Saenz 2018, Orgel 2016, Amankwah 2016). Saenz et al reported increased risk of mortality for overweight/obese ALL and AML patients in a single institution study of 181 patients and a meta-analysis (Saenz 2018). In multivariate analysis, there was no difference in relapse incidence or mortality between overweight/obese and non-overweight children. ${ }^{10}$ However, two meta-analyses conducted before found out that a high BMI was associated with poorer survival in pediatric patients with acute leukemia. ${ }^{11,12}$

The potential correlation between age, BMI and survival remains unclear. Diet and the socio-economic status vary among countries worldwide, and whether being underweight or obese affects survival in pediatric ALL and AML continues to be a matter of debate. ${ }^{13}$

This review aims to report the outcomes in children with AML and ALL and the possible association with BMI.

\section{Body Mass Index and Acute Lymphoblastic Leukemia}

In 2006, a retrospective study reported outcomes, toxicity and pharmacokinetics across four BMI groups of 621 children receiving induction chemotherapy for ALL. Overall survival (OS), event-free-survival (EFS) and relapse incidence were not significantly different through the four BMI groups. Similarly, the authors did not observe differences in toxicities and pharmacokinetics between the groups (Hijiya 2006). ${ }^{14}$ In the same year, a more restricted analysis performed on 322 children with ALL reported that obesity at diagnosis was not associated with a decreased OS and EFS (Baillargeon 2006). ${ }^{15}$

The Nordic Society of Pediatric Hematology and Oncology reported a higher risk of osteonecrosis as treatment-related toxicity after chemotherapy in children with ALL who had a high BMI. Twenty-three of the 97 children analyzed experienced osteonecrosis, of whom seven asymptomatic and 10 requiring surgical intervention. A BMI $\geq 95$ th percentile was more frequent among children who experienced osteonecrosis $(\mathrm{p}=0.02)$ and it was confirmed as an independent risk factor in multivariate analysis $(\mathrm{p}=0.04)$ (Niinimäki 2007). ${ }^{16}$

In 2007, the outcomes of 4260 pediatric patients with ALL were studied with the hypothesis that obese children were at higher risk of relapse. The idea was that obese patients received lower doses of chemotherapy, which is normally dosed on body-surface area. In univariate analysis, obesity was associated with worse outcome in patients older than 10 years (HR 1.48, 95\% CI 1.07-2.03, $\mathrm{p}=0.01$ ). When looking separately in patients diagnosed before and after the age of 10 years, the effect of obesity was confirmed in patients older than 10 years also in the verification cohort. On the contrary, obesity was not associated with a poor outcome for patients aged less than 10 years. In multivariate analysis, obesity was an independent factor associated with poor outcome (HR for EFS 1.36, 95\% CI 1.04-1.77, $\mathrm{p}=0.02$; HR for relapse 1.29, 95\% CI 1.02-1.56, $\mathrm{p}=0.04$ ) (Butturini 2007). ${ }^{9}$

Being overweight or obese at diagnosis was an independent negative prognostic factor for the 5-year EFS in retrospective study conducted in 181 pediatric patients with ALL. A low EFS was observed in obese/overweight who were in intermediate and high-risk groups (relapse risk according ALL-BMF95 trial) than in non-overweight $(\mathrm{p}=0.02)\left(\right.$ Gelete 2011). ${ }^{17}$

Orgel et al reported outcomes of 198 children with B-cell ALL undergoing induction chemotherapy with the 
aim of evaluating the impact of BMI on outcome $(n=127$ lean, $n=30$ overweight, $n=41$ obese). They found that the children overweight and obese were at higher risk for a positive minimal residual disease (MRD) after induction chemotherapy $(p=0.016)$. MRD was analyzed also as a continuous variable and the prevalence of positive MRD according BMI percentile was showed. This report first demonstrated that obesity at diagnosis was associated with an increased risk of persistent minimal disease after induction chemotherapy in pediatric ALL. In multivariate analysis, obesity was independently associated with lower EFS ( $p=0.012$ ). Of note, the cohort consisted of a majority of Hispanic children $(\mathrm{n}=157)$, a population especially prone to obesity (Orgel 2014). ${ }^{18}$

In the same year, 1033 children with standard risk ALL have been reported from the Medical Research Council consortium. No differences were observed in outcomes and relapse incidence among obese and overweight children versus healthy and underweight groups (Aldhafiri 2014). ${ }^{19}$

In 2015, 762 pediatric patients with B-cell and T-cell ALL were reported with the aim of analyzing the influence of BMI on outcome. Multivariate analysis showed similar OS and EFS across the groups but a higher relapse risk in patients underweight (HR 1.88, 95\% CI 1.13-3.13). In addition, a decrease in BMI during the first 32 weeks of treatment was associated with a lower survival (den Hoed 2015). ${ }^{20}$

The effect of BMI at diagnosis was analyzed on 373 children with B and T-cell ALL. No differences were found according the BMI groups and relapse incidence or EFS. In multivariate analysis, obese patients had worse OS compared with non-obese $(p=0.031)$. MRD levels on day 19 and 46, relapse incidence, EFS and OS were not associated with BMI percentile change between diagnosis and the end of induction (Eissa 2017). ${ }^{21}$

A retrospective study performed in 103 children with ALL treated at the Children's Cancer Institute in Lebanon reported a trend showing poor outcomes (death and relapse) in malnourished children (Yazbeck 2016). ${ }^{22}$

The role of malnutrition has also been explored in a multicenter cohort of Mexican children. The study enrolled 794 newly diagnosed ALL. In multivariate analysis, a high risk of mortality $(\mathrm{RR}=2.08$, 95\% CI 1.08 4.01) was observed in the group of malnourished children with a high-risk ALL (Martín-Trejo 2017). ${ }^{23}$ More recently, the Mexican inter-institutional group for the identification of the causes of childhood leukemia group has reported outcomes of 1070 children younger than 15 years old who were diagnosed with B and T-cell ALL with the purpose of identifying BMI at diagnosis as a predictor of higher risk of mortality or relapse. Patients were followed for 24 months after diagnosis and were categorized according $\mathrm{CDC}$ and WHO classification for BMI. In both cases, when comparing obese to normal and overweight group, significant differences in OS were noticeable ( $p=0.003$ and $p=0.01$, respectively). However, no association with early relapse was observed according to BMI group (Núñez-Enríquez 2019). ${ }^{24}$

No statistically significant association was found by the Nordic Society of Pediatric Hematology Oncology between a higher BMI and the risk of pancreatitis in children with ALL (Mogensen 2018). ${ }^{25}$ More recently, a decrease in BMI percentile during chemotherapy treatment for intermediate-risk pediatric ALL was associated with higher incidence of infectious and febrile episodes $\left(p=0.04\right.$ and $p=0.006$, respectively) (Chaber 2019). ${ }^{26}$ Furthermore, obesity was reported as a risk factor for adverse events (treatment-requiring hypertension $[\mathrm{p}=$ 0.0497], insulin-requiring hyperglycemia $[\mathrm{p}=0.04]$, recurrent admission-requiring infections $[p=0.02]$ and recurrent febrile neutropenia admissions $[\mathrm{p}=0.01]$ ) in a cohort of 155 pediatric patients during pre-maintenance chemotherapy for ALL (Meenan 2019). ${ }^{27}$

In addition, published research suggests that weight gain during induction chemotherapy is associated with obesity at the end of the treatment, but the impact of this change in weight on outcomes is not known. ${ }^{28-31}$ Daily body weight measurement ${ }^{30}$ is one of the preventive measures to take into consideration to avoid the excess body gain. However, other pre-emptive measures should be considered in the future analysis. Table 1 resumes the main outcomes according to studies on BMI and ALL reported in the literature (Table 1).

Overall, the reported studies support the existence of an adverse association between a higher BMI and increased relapse incidence and mortality in pediatric patients with ALL. One could hypothesize a variation in chemotherapy metabolism in the obese, as suggested from preclinical studies, but prospective trials have not found such differences in ALL pediatric patients. Furthermore, whether treatment with glucocorticoids has a long-lasting influence on obesity in pediatric ALL survivors is not well established. Previous studies report a pattern of weight changes in patients with ALL during therapy, due to corticosteroid exposure and related insulin resistance. ${ }^{32}$ 
Table I ALL and BMI

\begin{tabular}{|c|c|c|c|c|c|c|}
\hline References & $\mathbf{n}$ & ALL Subtype & $\begin{array}{l}\text { Chemotherapy } \\
\text { Regimens }\end{array}$ & $\begin{array}{l}\text { BMI Groups } \\
\text { Definition }\end{array}$ & $\begin{array}{l}\text { Age } \\
\text { Range, } Y\end{array}$ & Outcomes \\
\hline $\begin{array}{l}\text { Nunez-Enriquez JC, } \\
\text { BMC Cancer } 2019^{24}\end{array}$ & 1070 & $\begin{array}{l}\text { B cell }=931 \\
\text { Biphenotypic= } 37 \\
\text { T cell= } 102\end{array}$ & Not mentioned & $\begin{array}{l}\text { WHO } \\
\text { CDC }\end{array}$ & $0-15$ & $\begin{array}{l}\text { Overweight and obese had } \\
\text { higher early mortality }\end{array}$ \\
\hline $\begin{array}{l}\text { Martín-Trejo JA, Leuk } \\
\text { Lymph } 2017^{23}\end{array}$ & 794 & $\begin{array}{l}B \text { cell }=706 \\
T \text { cell }=88\end{array}$ & Not mentioned & $\begin{array}{l}\text { WHO } \\
\text { CDC }\end{array}$ & $0-17$ & $\begin{array}{l}\text { High risk of dying in } \\
\text { malnourished children with } \\
\text { a high-risk ALL }\end{array}$ \\
\hline $\begin{array}{l}\text { Eissa HM, Blood } \\
\text { Cancer J } 2017^{21}\end{array}$ & 373 & $\begin{array}{l}\text { B cell }=310 \\
T \text { cell }=63\end{array}$ & Total XV protocol & $\mathrm{CDC}$ & $2-17.9$ & $\begin{array}{l}\text { No differences in relapse } \\
\text { incidence and EFS } \\
\text { Obese had worse OS }\end{array}$ \\
\hline $\begin{array}{l}\text { Niinimaki RA, JCO } \\
2007^{16}\end{array}$ & 97 & $\begin{array}{l}\text { All B cell } \\
\text { precursor }\end{array}$ & $\begin{array}{l}\text { ALL-NSPHO 86, 92, } \\
2000\end{array}$ & Finnish norms & $1-15$ & $\begin{array}{l}\text { High BMI associated with } \\
\text { radiographic osteonecrosis }\end{array}$ \\
\hline $\begin{array}{l}\text { den Hoed MAH, } \\
\text { Haematologica } 2015^{20}\end{array}$ & 703 & $\begin{array}{l}\text { B cell }=573 \\
T \text { cell }=130\end{array}$ & DCOG - ALLI9 & WHO & $2-17$ & $\begin{array}{l}\text { Higher relapse risk in } \\
\text { underweight, but similar OS } \\
\text { and EFS }\end{array}$ \\
\hline Hijiya N, Blood $2006^{14}$ & 621 & $\begin{array}{l}\text { B cell }=516 \\
T \text { cell }=105\end{array}$ & $\begin{array}{l}\text { Total XII, XIIIA, } \\
\text { XIIIB, XIV }\end{array}$ & $\mathrm{CDC}$ & $1.01-18.08$ & $\begin{array}{l}\text { EFS, OS relapse incidence and } \\
\text { toxicities did not differ among } \\
\text { the } 4 \mathrm{BMI} \text { groups }\end{array}$ \\
\hline $\begin{array}{l}\text { Butturini AM, JCO } \\
2007^{9}\end{array}$ & 4260 & $\begin{array}{l}\text { B cell }=473 * \\
\text { T cell }=136 \\
\text { Other }=77\end{array}$ & $\begin{array}{l}\text { CCG-1922, I89I, } \\
\mid 882,1901\end{array}$ & CDC & $2-19.99$ & $\begin{array}{l}\text { Higher EFS and relapse } \\
\text { incidence in } \geq 10 \text { years }\end{array}$ \\
\hline $\begin{array}{l}\text { Gelelete CB, Obesity, } \\
2011^{17}\end{array}$ & 181 & $\begin{array}{l}\text { B cell }=144 \\
T \text { cell }=36\end{array}$ & $\begin{array}{l}\text { BMF90, BFM95, } \\
\text { BFM2002 }\end{array}$ & WHO & $\leq 10-18$ & $\begin{array}{l}5-y \text { EFS lower in overweight/ } \\
\text { obese }\end{array}$ \\
\hline $\begin{array}{l}\text { Yazbeck N, J Pediatr } \\
\text { Oncol } 2016^{22}\end{array}$ & 103 & $B$ and $T$ cell & Not mentioned & $\begin{array}{l}\text { WHO } \\
\text { CDC }\end{array}$ & $0-17$ & $\begin{array}{l}\text { Trend showing worse outcomes } \\
\text { in malnourished children (death } \\
\text { and relapse) }\end{array}$ \\
\hline Orgel E, Blood $2014^{18}$ & 198 & $\begin{array}{l}\text { All B cell } \\
\text { precursor }\end{array}$ & $\begin{array}{l}\text { CCG-199I, I96I; } \\
\text { AALL033I, 0932, } \\
\text { 08PI, 0232, II3I }\end{array}$ & $\begin{array}{l}\text { CDC } \\
\text { WFLs Iy }\end{array}$ & 121 & $\begin{array}{l}\text { Obesity at induction associated } \\
\text { with greater risk of persistent } \\
\text { MRD }\end{array}$ \\
\hline $\begin{array}{l}\text { Baillargeon J, J Pediatr } \\
\text { Oncol } 2006^{15}\end{array}$ & 322 & B cell & Not mentioned & $\begin{array}{l}\text { WHO } \\
\text { CDC }\end{array}$ & $0-18$ & $\begin{array}{l}\text { Obesity not associated with } \\
\text { decreased OS or EFS }\end{array}$ \\
\hline $\begin{array}{l}\text { Aldhafiri FK, J Pediatr } \\
\text { Hematol Oncol } 2014^{19}\end{array}$ & 1033 & $\begin{array}{l}\text { All B cell } \\
\text { precursor }\end{array}$ & UK ALL-X & $\begin{array}{l}\text { BMI according } \\
\text { international } \\
\text { survey thresholds }\end{array}$ & $2-14.9$ & $\begin{array}{l}\text { Relapse incidence was no } \\
\text { different among the } 4 \text { groups }\end{array}$ \\
\hline
\end{tabular}

Note: *Data available for pts $\geq 10$ years.

Abbreviations: BMI, body mass index; WHO, World Health Organisation; CDC, Centers of Disease Control; ALL, acute lymphoblastic leukemia; NSPHO, Nordic Society of Pediatric Hematology and Oncology; OS, overall survival; EFS, event-free survival; DCOG, Dutch Childhood Oncology Group; CCG, Children's Cancer Group; WFL, weight-for-length; MRD, minimal residual disease. 
Biological mechanisms that modify the risk of obesity by gender and age at diagnosis have been proposed (insulin growth factor, leptin) but remain speculative and longer follow up prospective studies are needed.

\section{BMI and Acute Myeloid Leukemia}

In 2005, poor outcome in obese and underweight children treated in the Children Cancer Group (CCG) 2961 was first reported. Both underweight and overweight children with AML had increased treatment toxicities and decreased OS. Survival and EFS at 3 years were significantly lower in obese children $(\mathrm{p}<0.001$ and $\mathrm{p}=0.009$, respectively). Inferior outcomes were due to treatmentrelated mortality in the first months of chemotherapy (Lange 2005). ${ }^{8}$

Inaba et al detailed outcomes of 314 children with AML enrolled in four St. Jude protocols and grouped according to BMI. The 5-year OS of overweight/obese was lower than that of patients with healthy weight (46.5\% versus $67.1 \%$, $\mathrm{P}<.001)$. In a multivariable analysis, patients with normal BMI had the best survival rate among the 3 groups $(p=0.01)$. When BMI was considered as a continuous variable, patients with lower or higher BMI percentiles had worse survival $(\mathrm{p}=0.03)$. Underweight and overweight/obese patients had a significantly higher cumulative incidence of treatmentrelated mortality, especially due to infection $(p=0.009)$ (Inaba 2012). ${ }^{33}$

Subsequently, the analysis of combined data from the CCG-2891, CCG-2941, CCG-2961, and AAML03P1 trials was reported. The data-set included 1840 patients, 238 from 16 to 20 years old, and 1602 aged less than 16 years old. In multivariate model, being overweight was independently associated with treatment-related mortality $(\mathrm{HR}=2.18$, $95 \% \mathrm{CI}=1.42-3.36, \mathrm{p}<0.001)$, poorer OS $(\mathrm{HR}=1.56$, $95 \% \mathrm{CI}=1.21-2.03, \mathrm{p}<.001)$ and $\mathrm{EFS}(\mathrm{HR}=1.36,95 \%$ $\mathrm{CI}=1.08-1.73, \mathrm{p}=0.011)\left(\right.$ Canner 2013). ${ }^{34}$

In contrast, being overweight or obese was not associated with poor outcomes in a cohort of 58 Taiwanese children with AML. Despite the limited number of patients, this single-center experience reported comparable OS and EFS among the 3 BMI groups (underweight, $n=3$, healthy, $n=40$, overweight, $n=15)$ (Chen 2015). ${ }^{35}$

The Northern Society of Pediatric Hematology and Oncology described outcomes and toxicities after chemotherapy protocol AML 2004 and reported also the impact of BMI in 318 children. In this cohort, being overweight was associated with a higher risk of being bedridden and requiring supplemental oxygen $(\mathrm{HR}=1.9,95 \%$
$\mathrm{CI}=1.0-3.5, \mathrm{p}=0.04)$. For children aged 10 to 17 years old, being overweight was associated with a trend for superior EFS $(59 \%$ versus $40 \%, \mathrm{p}=0.09)$ and OS $(78 \%$ versus $56 \%, \mathrm{p}=0.06$ ) compared to healthy weight children. On the contrary, in children aged 2 to 9 years EFS and OS were not significantly different when comparing overweight and healthy weight. These data suggested a possible different pharmacokinetics of chemotherapy drugs in adolescents and children (Løhmann 2016). ${ }^{36}$

Recently, the association of BMI and outcome was in a large multicenter cohort of 867 children with AML. The study included children diagnosed in the last twenty years and correlated cytogenetic abnormalities with BMI also. No difference in relapse risk, TRM; 5-year OS was reported across the four BMI groups. Importantly, obese patients had a higher frequency of $t(8 ; 21)$ and $\operatorname{inv}(16)$ (Løhmann 2019). ${ }^{37}$ Table 2 shows outcomes according to studies on BMI and AML (Table 2).

As for pediatric ALL, the included studies reported an association of poorer OS in AML pediatric patients with a higher BMI. Conversely, a higher toxicity was observed in several of these reports. Therefore, on could assume that poor survival is due to greater treatment-related mortality rather than relapse in these acute leukemia subtypes. Nevertheless, the pathophysiology of the association between higher BMI and AML pediatric outcomes is probably multifactorial and still need to be clarified throughout epidemiological and biological studies.

\section{BMI and Acute Leukemia Undergoing Hematopoietic Cell Transplantation}

BMI may have an impact on outcome after allogeneic hematopoietic cell transplantation (HCT) (Gleimer 2015). ${ }^{38}$ Obesity and undernourishment have been associated with complications and inferior outcomes after HCT in pediatric patients, but the majorities of the studies are heterogeneous and not exclusive to acute leukemia. Bulley et al reported a heterogeneous cohort of 325 children, including 192 with acute leukemia, undergoing HCT. This single-center study, comprising different stem cell sources and conditioning regimens, demonstrated inferior OS in overweight patients compared to normal BMI ( $\mathrm{p}=0.02)$ (Bulley 2008). ${ }^{39}$

No association between poor outcomes and being obese or undernourished was found in a cohort of 200 children (of whom ALL, n=113; AML, n=55) who underwent umbilical cord blood transplantation (Pine 2011). ${ }^{40}$ 
Table 2 AML and BMI

\begin{tabular}{|c|c|c|c|c|c|}
\hline References & $\mathbf{n}$ & Chemotherapy Regimens & $\begin{array}{l}\text { BMI } \\
\text { Groups } \\
\text { Definition }\end{array}$ & $\begin{array}{l}\text { Age } \\
\text { Range, } \\
\text { Y }\end{array}$ & Outcomes \\
\hline $\begin{array}{l}\text { Lohmann DJ, Haematologica } \\
2016^{35}\end{array}$ & 318 & NOPHO-AML 2004 & WHO & $0-17$ & $\begin{array}{l}\text { Overweight associated with requirement } \\
\text { in supplemental oxygen } \\
\text { Overweight and aged 10-17 higher risk } \\
\text { of grade 3-4 toxicity }\end{array}$ \\
\hline Chen SH, Int J Hematol $2015^{34}$ & 58 & TPOG-AML-97 & WHO & $0-18$ & $\begin{array}{l}\text { 5-y EFS was not significantly different } \\
\text { among BMI groups }\end{array}$ \\
\hline Canner J, Cancer $2013^{33}$ & 1840 & $\begin{array}{l}\text { CCG-289I, 294I, 296I, } \\
\text { AAML03PI }\end{array}$ & $\begin{array}{l}\text { WFL } \leq 1 \text { y } \\
\text { CDC }\end{array}$ & $0.01-20.9$ & $\begin{array}{l}\text { Overweight had higher risk for TRM, EFS } \\
\text { and OS }\end{array}$ \\
\hline Inaba $\mathrm{H}$, Cancer $2012^{32}$ & 314 & AML87, 91, 9, 02 & CDC & $2-19.9$ & $\begin{array}{l}\text { Lower } 5 \text {-y OS in children overweight and } \\
\text { obese } \\
\text { Higher TRT in underweight }\end{array}$ \\
\hline Lange BJ, JAMA $2005^{8}$ & 768 & CCG-296I & CDC & $0.01-20.9$ & Lower 3-y OS and EFS in obese \\
\hline $\begin{array}{l}\text { Lohmann DJ, Cancer Med } \\
2019^{36}\end{array}$ & 867 & $\begin{array}{l}\text { AAML053I,I5; COG942I,I6; } \\
\text { NOPHO-AML 2004,I7 DB } \\
\text { AML-0I,18; NOPHO-DBH } \\
\text { AML 20I2 }\end{array}$ & WHO & & $\begin{array}{l}\text { No difference in relapse risk, TRM, } \\
5 \text {-year OS across the BMI groups } \\
\text { Obese patients had a higher frequency of } \\
t(8 ; 2 I) \text { and inv }(16)\end{array}$ \\
\hline
\end{tabular}

Abbreviations: BMI, body mass index; WHO, World Health Organization; CDC, Centers of Disease Control; NOPHO, Nordic Society for Pediatric Hematology and Oncology; OS, overall survival; EFS, event-free survival; DCOG, Dutch Childhood Oncology Group; CCG, Children's Cancer Group; WFL, weight-for-length; TPOG, Taiwan Pediatric Oncology protocol.

The impact of pre-HCT BMI together on outcomes has been analyzed in 733 patients (ALL, $\mathrm{n}=395 ; \mathrm{AML}, \mathrm{n}=189$; other hematological malignancies, $\mathrm{n}=145)$ aged 2 to 18 years. The BMI 5th-24th percentile group had lower EFS $(\mathrm{p}=0.01)$ and higher relapse $(\mathrm{p}=0.003)$ at day +100 postHCT (Hoffmeister 2013) ${ }^{41}$.

Aplenc and colleagues reported no difference in OS after HCT according to four BMI classes among children in a large retrospective study. The analysis included 3687 patients aged 2 to 19 years with AML, ALL, chronic myeloid leukemia and myelodysplastic syndrome. Obese children had less relapse after HCT but higher transplantrelated mortality (Aplenc 2014). ${ }^{42}$

More recently, the impact of BMI has been reported in a retrospective study including 855 children with acute leukemia (ALL, $\mathrm{n}=577$; AML, $\mathrm{n}=278$ ) undergoing single umbilical cord blood transplantation. In multivariate analysis, a BMI $<5$ th percentile was associated with higher incidence of acute grade II to IV graftversus-host disease compared with normal-BMI patients $(p=0.006)$ (Paviglianiti 2018). ${ }^{43}$

\section{Conclusion}

The association between BMI and acute leukemia outcomes after chemotherapy and/or HSCT remains controversial. Being at either extreme of the index (underweight or obese) is associated with worse outcomes and toxicities. The inclusion of different chemotherapy protocols, leukemia subtypes analyzed, diet habits and differences between high and low-income countries are some of the factors that could lead to misinterpretation of the data.

However, BMI remains an important tool to characterize the nutritional status of children with AML or ALL before chemotherapy treatment or HCT. Nutritional evaluation should be taken into account before any type of cancer treatment. Inappropriate dose of chemotherapy drugs due to obesity condition or for being undernourished might be associated to poorer prognosis in pediatric AML and ALL. However, the biology of adipose tissue, hormone and genetic interactions needs to be better understood. BMI is only a surrogate measure of body fat because it measures excess weight rather than excess fat. In other words, BMI does not distinguish between excess fat, muscle, or bone mass, nor does it provide any indication of the distribution of fat among individuals.

Understanding the prognostic impact of obesity on pediatric cancer outcomes has both clinical and public health implications for preventive intervention that could improve outcomes. The higher incidence of obesity worldwide solicits for prospective investigation to provide the prompt intervention and improving outcomes of children with acute leukemia. 


\section{Acknowledgments}

The author would like to thank Fernanda Volt, MT, MSc (Eurocord, Paris) for critical reading of this manuscript.

\section{Disclosure}

The author reports no conflicts of interest in this work.

\section{References}

1. Ward E, DeSantis C, Robbins A, Kohler B, Jemal A. Childhood and adolescent cancer statistics, 2014. CA Cancer J Clin. 2014;64 (2):83-103. doi:10.3322/caac.21219

2. Rogers PC, Meacham LR, Oeffinger KC, Henry DW, Lange BJ. Obesity in pediatric oncology. Pediatr Blood Cancer. 2005;45 (7):881-891. doi:10.1002/pbc.20451

3. Pietrobelli A, Faith MS, Allison DB, Gallagher D, Chiumello G, Heymsfield SB. Body mass index as a measure of adiposity among children and adolescents: a validation study. J Pediatr. 1998;132 (2):204-210. doi:10.1016/s0022-3476(98)70433-0

4. Ogden CL, Kuczmarski RJ, Flegal KM, et al. Centers for Disease Control and Prevention 2000 growth charts for the United States: improvements to the 1977 National Center For Health Statistics version. Pediatrics. 2002;109(1):45-60. doi:10.1542/peds.109.1.45

5. Iyengar NM, Gucalp A, Dannenberg AJ, Hudis CA. Obesity and cancer mechanisms: tumor microenvironment and inflammation. $J$ Clin Oncol. 2016;34(35):4270-4276. doi:10.1200/JCO.2016.67. 4283

6. Cheymol G. Effects of obesity on pharmacokinetics implications for drug therapy. Clin Pharmacokinet. 2000;39(3):215-231. doi:10.2165/ 00003088-200039030-00004

7. Jain R, Chung SM, Jain L, et al. Implications of obesity for drug therapy: limitations and challenges. Clin Pharmacol Ther. 2011;90 (1):77-89. doi:10.1038/clpt.2011.104

8. Lange BJ, Gerbing RB, Feusner J, et al. Mortality in overweight and underweight children with acute myeloid leukemia. JAMA. 2005;293 (2):203-211. doi:10.1001/jama.293.2.203

9. Butturini AM, Dorey FJ, Lange BJ, et al. Obesity and outcome in pediatric acute lymphoblastic leukemia. J Clin Oncol. 2007;25 (15):2063-2069. doi:10.1200/JCO.2006.07.7792

10. Saenz AM, Stapleton S, Hernandez RG, et al. Body mass index at pediatric leukemia diagnosis and the risks of relapse and mortality: findings from a single institution and meta-analysis. $J$ Obes. 2018;2018:7048078. doi:10.1155/2018/7048078

11. Orgel E, Genkinger JM, Aggarwal D, Sung L, Nieder M, Ladas EJ. Association of body mass index and survival in pediatric leukemia: a meta-analysis. Am J Clin Nutr. 2016;103(3):808-817. doi:10.3945/ ajcn.115.124586

12. Amankwah EK, Saenz AM, Hale GA, Brown PA. Association between body mass index at diagnosis and pediatric leukemia mortality and relapse: a systematic review and meta-analysis. Leuk Lymphoma. 2016;57(5):1140-1148. doi:10.3109/10428194.2015.107 6815

13. Popkin BM. The nutrition transition: an overview of world patterns of change. Nutr Rev. 2004;62(7):S140-143. doi:10.1111/j.1753-4887. 2004.tb00084.x

14. Hijiya N, Panetta JC, Zhou Y, et al. Body mass index does not influence pharmacokinetics or outcome of treatment in children with acute lymphoblastic leukemia. Blood. 2006;108(13):39 97-4002. doi:10.1182/blood-2006-05-024414

15. Baillargeon J, Langevin A-M, Lewis M, et al. Obesity and survival in a cohort of predominantly Hispanic children with acute lymphoblastic leukemia. J Pediatr Hematol Oncol. 2006;28(9):575-578. doi:10. 1097/01.mph.0000212985.33941.d8
16. Niinimäki RA, Harila-Saari $\mathrm{AH}$, Jartti $\mathrm{AE}$, et al. High body mass index increases the risk for osteonecrosis in children with acute lymphoblastic leukemia. J Clin Oncol. 2007;25(12):1498-1504. doi:10.1200/JCO.2006.06.2539

17. Gelelete CB, Pereira SH, Azevedo AMB, et al. Overweight as a prognostic factor in children with acute lymphoblastic leukemia. Obes Silver Spring Md. 2011;19(9):1908-1911. doi:10.1038/oby.20 11.195

18. Orgel E, Tucci J, Alhushki W, et al. Obesity is associated with residual leukemia following induction therapy for childhood B-precursor acute lymphoblastic leukemia. Blood. 2014;124 (26):3932-3938. doi:10.1182/blood-2014-08-595389

19. Aldhafiri FK, McColl JH, Reilly JJ. Prognostic significance of being overweight and obese at diagnosis in children with acute lymphoblastic leukemia. J Pediatr Hematol Oncol. 2014;36(3):234-236. doi:10.1097/MPH.0000000000000056

20. den Hoed MA, Pluijm SMF, de Groot-kruseman HA, et al. The negative impact of being underweight and weight loss on survival of children with acute lymphoblastic leukemia. Haematologica. 2015;100(1):62-69. doi:10.3324/haematol.2014.110668

21. Eissa HM, Zhou Y, Panetta JC, et al. The effect of body mass index at diagnosis on clinical outcome in children with newly diagnosed acute lymphoblastic leukemia. Blood Cancer J. 2017;7(2):e531. doi:10. 1038/bcj.2017.11

22. Yazbeck N, Samia L, Saab R, Abboud MR, Solh H, Muwakkit S. Effect of malnutrition at diagnosis on clinical outcomes of children with acute lymphoblastic leukemia. J Pediatr Hematol Oncol. 2016;38(2):107-110. doi:10.1097/MPH.0000000000000428

23. Martín-Trejo JA, Núñez-Enríquez JC, Fajardo-Gutiérrez A, et al. Early mortality in children with acute lymphoblastic leukemia in a developing country: the role of malnutrition at diagnosis. A multicenter cohort MIGICCL study. Leuk Lymphoma. 2017;58 (4):898-908. doi:10.1080/10428194.2016.1219904

24. Núñez-Enríquez JC, Gil-Hernández AE, Jiménez-Hernández E, et al. Overweight and obesity as predictors of early mortality in Mexican children with acute lymphoblastic leukemia: a multicenter cohort study. BMC Cancer. 2019;19(1):708. doi:10.1186/s12885019-5878-8

25. Mogensen PR, Wolthers BO, Grell K, Schmiegelow K, Frandsen TL. Association between body mass index and pancreatitis in children with acute lymphoblastic leukemia. Pediatr Blood Cancer. 2018;65 (8):e27071. doi:10.1002/pbc.27071

26. Chaber R, Latos-Grażyńska E, Ciebiera K, et al. Body Mass Index (BMI) and Infectious/Febrile Episodes in Children with Intermediate Risk Acute Lymphoblastic Leukemia (IR ALL). Nutr Cancer. 2019;71(4):701-707. doi:10.1080/01635581.2018.1516792

27. Meenan CK, Kelly JA, Wang L, Ritchey AK, Maurer SH. Obesity in pediatric patients with acute lymphoblastic leukemia increases the risk of adverse events during pre-maintenance chemotherapy. Pediatr Blood Cancer. 2019;66(2):e27515. doi:10.1002/pbc.27515

28. Withycombe JS, Smith LM, Meza JL, et al. Weight change during childhood acute lymphoblastic leukemia induction therapy predicts obesity: a report from the Children's Oncology Group. Pediatr Blood Cancer. 2015;62(3):434-439. doi:10.1002/pbc.25316

29. Browne EK, Zhou Y, Chemaitilly W, et al. Changes in body mass index, height, and weight in children during and after therapy for acute lymphoblastic leukemia. Cancer. 2018;124(21):4248-4259. doi: $10.1002 /$ cncr.31736

30. Seki Y, Okamoto Y, Kodama Y, et al. Risk factors and the prevention of weight gain during induction chemotherapy in children with acute lymphoblastic leukemia. J Pediatr Hematol Oncol. 2018;40(6):e334e337. doi:10.1097/MPH.0000000000001098

31. Hill R, Hamby T, Bashore L, et al. Early nutrition intervention attenuates weight gain for pediatric acute lymphoblastic leukemia patients in maintenance therapy. J Pediatr Hematol Oncol. 2018;40 (2):104-110. doi:10.1097/MPH.0000000000000975 
32. Esbenshade AJ, Simmons JH, Koyama T, Koehler E, Whitlock JA, Friedman DL. Body mass index and blood pressure changes over the course of treatment of pediatric acute lymphoblastic leukemia. Pediatr Blood Cancer. 2011;56(3):372-378. doi:10.1002/pbc.22 782

33. Inaba H, Surprise HC, Pounds S, et al. Effect of body mass index on the outcome of children with acute myeloid leukemia. Cancer. 2012;118(23):5989-5996. doi:10.1002/cncr.27640

34. Canner J, Alonzo TA, Franklin J, et al. Differences in outcomes of newly diagnosed acute myeloid leukemia for adolescent/young adult and younger patients: a report from the Children's Oncology Group. Cancer. 2013;119(23):4162-4169. doi:10.1002/ cncr.28342

35. Chen S-H, Jaing T-H, Hung I-J, Yang C-P, Chang T-Y. High body mass index did not result in poor outcome in Taiwanese children with acute myeloid leukemia: a single-institution experience. Int J Hematol. 2015;102(1):48-52. doi:10.1007/s12185-015-17 95-Z

36. DJA L, Abrahamsson J, Ha S-Y, et al. Effect of age and body weight on toxicity and survival in pediatric acute myeloid leukemia: results from NOPHO-AML 2004. Haematologica. 2016;101(11):1359-13 67. doi:10.3324/haematol.2016.146175

37. Løhmann DJA, Asdahl PH, Abrahamsson J, et al. Associations between pretherapeutic body mass index, outcome, and cytogenetic abnormalities in pediatric acute myeloid leukemia. Cancer Med. 2019;8(15):6634-6643. doi:10.1002/cam4.2554
38. Gleimer M, Li Y, Chang L, et al. Baseline body mass index among children and adults undergoing allogeneic hematopoietic cell transplantation: clinical characteristics and outcomes. Bone Marrow Transplant. 2015;50(3):402-410. doi:10.1038/bmt.2014.280

39. Bulley S, Gassas A, Dupuis LL, et al. Inferior outcomes for overweight children undergoing allogeneic stem cell transplantation. Br J Haematol. 2008;140(2):214-217. doi:10.1111/j.1365-2141.2007.06900.x

40. Pine M, Wang L, Harrell FE, et al. The effect of obesity on outcome of unrelated cord blood transplant in children with malignant diseases. Bone Marrow Transplant. 2011;46(10):1309-1313. doi:10. 1038/bmt.2010.312

41. Hoffmeister PA, Storer BE, Macris PC, Carpenter PA, Baker KS. Relationship of body mass index and arm anthropometry to outcomes after pediatric allogeneic hematopoietic cell transplantation for hematologic malignancies. Biol Blood Marrow Transplant. 2013;19 (7):1081-1086. doi:10.1016/j.bbmt.2013.04.017

42. Aplenc R, Zhang M-J, Sung L, et al. Effect of body mass in children with hematologic malignancies undergoing allogeneic bone marrow transplantation. Blood. 2014;123(22):3504-3511. doi:10.1182/blood2013-03-490334

43. Paviglianiti A, Dalle JH, Ayas M, et al. Low body mass index is associated with increased risk of acute GVHD after umbilical cord blood transplantation in children and young adults with acute leukemia: a study on behalf of Eurocord and the EBMT pediatric disease working party. Biol Blood Marrow Transplant. 2018;24(4):799-805. doi:10.1016/j.bbmt.2017.12.790
Journal of Blood Medicine

\section{Publish your work in this journal}

The Journal of Blood Medicine is an international, peer-reviewed, open access, online journal publishing laboratory, experimental and clinical aspects of all aspect pertaining to blood based medicine including but not limited to: Transfusion Medicine; Blood collection, Donor issues, Transmittable diseases, and Blood banking logistics; Immunohematology; Artificial and alternative blood based

\section{Dovepress}

therapeutics; Hematology; Biotechnology/nanotechnology of blood related medicine; Legal aspects of blood medicine; Historical perspectives. The manuscript management system is completely online and includes a very quick and fair peer-review system. Visit http://www.dovepress.com/testimonials.php to read real quotes from published authors. 